Issue 8, 2020

https://doi.org/10.23939/sisn2020.08.065

УДК 004.4

\title{
MOBILE INFORMATION SYSTEM FOR MONITORING THE SPREAD OF VIRUSES IN SMART CITIES
}

\author{
Oleksii Duda ${ }^{1}$, Liliana Dzhydzhora ${ }^{1}$, Oleksandr Matsiuk ${ }^{1}$, Andrii Stanko ${ }^{1}$, \\ Nataliia Kunanets ${ }^{2}$, Volodymyr Pasichnyk ${ }^{2}$, Oksana Kunanets ${ }^{2}$ \\ ${ }^{1}$ Ternopil Ivan Puluj National Technical University \\ oleksij.duda@gmail.com, ORCID 0000-0003-2007-1271 \\ oleksandr.matsiuk@gmail.com, ORCID 0000-0003-0204-3971 \\ lilyadzhydzhora1970@gmail.com, ORCID 0000-0002-3672-4807 \\ stanko.andrjj@gmail.com, ORCID 0000-0002-5526-2599 \\ ${ }^{2}$ Lviv Polytechnic National University \\ nek.lviv@gmail.com, ORCID 0000-0003-3007-2462 \\ vpasichnyk@gmail.com, ORCID 0000-0002-5231-6395 \\ oksanka.kun@gmail.com, ORCID 0000-0001-8626-9016
}

(C) Duda O., Dzhydzhora L., Matsiuk O., Stanko A., Kunanets N., Pasichnyk V., Kunanets O., 2020

The concept of creating a multi-level mobile personalized system for fighting viral diseases, in particular Covid-19, was developed. Using the integration of the Internet of Things, Cloud Computing and Big Data technologies, the system involves a combination of two architectures: client-server and publication-subscription. The advantage of the system is the permanent help with viral diseases, namely on communication, information, and medical stages. The smart city concept in the context of viral disease control focuses on the application of Big Data analysis methods and the improvement of forecasting procedures and emergency treatment protocols. Using different technologies, cloud server stores the positioning data obtained from different devices, and the application accesses API to display and analyze the positioning data in real time. Due to the technologies combination, internal and external positioning can be used with a certain accuracy degree, being useful for various medical and emergency situations and analysis and the following processing by other smart city information systems. The result of the given investigation is the development of the conceptual model of multi-level mobile personalized health status monitoring system used for intellectual data analysis, prediction, treatment and prevention of viral diseases such as Covid-19 in modern "smart city".

Key words: smart city, IoT, virus.

\section{Introduction}

Integration of Internet of Things (IoT), cloud computing and Big Data technologies in health care field resulted in the "smart health" innovative concept development. "Smart health" is one of the elements of the "Smart City" system concept concerning medical services supply for prevention, diagnosis, treatment and further patients rehabilitation at any time and place by modern information technologies implementation.

It should be noted that IoT makes it possible for physical devices to collect and exchange data using modern information and communication technologies. Smart devices implemented in IoT enable doctors to perform preventive care, diagnosis and patients treatment more completely and comprehensively. They significantly improve the services quality and promote effective problem solution in health care such as patients' health status monitoring in real-time scale, especially with acute and chronic diseases (heart failure, arrhythmia, diabetes, asthma attacks, etc.). 
The introduction of Internet of Things (IoT) technologies contributes to improvement of monitoring, diagnosis and treatment methods and tools suitable and effective in problem solution in emergency cases, such as viral diseases outbreaks. Information technology based on the Internet of Things (IoT) technology use makes it possible to carry out the patients' health status monitoring in real time and qualitative and complete obtained data processing.

Covid-19 pandemic broken out in densely populated areas of China and ripped round the world, demonstrates the great importance of paying attention to the systems of monitoring, positioning and emergency response for viral threats. This approach generates the need to create integrated medical cyber-physical systems, particularly in the context of the "smart city" and "smart region" concepts implementation.

Information about disease progression should be received and processed in real-time making it possible to respond quickly and qualitatively to the emergence of new viral threats, to provide personalized, targeted and highly qualified medical care.

\section{Review of scientific publications}

Real-time remote patient health status monitoring systems generated the premises for rapid telemedicine development, innovative approaches promoting rapid monitoring data transfer to doctors, regardless of location, using modern information and communication technologies. Remote operational monitoring procedures for patient health status require continuous improvement as approaches for diagnosis the changes of patient health status indicators and as well as the means for real-time data transfer to the healthcare service providers. Such changes tracking is based on the application of information systems including information technologies based on sensors, communication systems, artificial intelligence etc.

Telemedicine is a new way of patient treatment protocols management providing the processes integrity health care field regardless of their location, and improving patient and doctor communication [1]. This method has numerous clinical advantages, but its implementation causes a number of problems including the healthcare system scale.

One of the first remote health monitoring systems, presented as integrated MobiHealth platform based on communication technology using only GPRS / UMTS is described in paper [2].

The authors of papers $[3,4]$ consider non-invasive biosensors and sensors providing patients health status monitoring in real time, as well as performing of non-invasive and convenient physiological measurements by replacing usual methods.

Smart contact lenses integrated with sensors for glucose level measurement, wireless messaging circuits, and LED image transmitters for glucose level control in tears are described in papers [3, 5], and ECG sensors use for monitoring several patients at the same time are described in [10].

The mobile phone use plays an important role in monitoring patients' health status to receive, transmit, and process remote patient examination data. The authors of paper [6] propose to use built-in clothes sensors (Body Sensor Network) reading in patient health status indicators and connected to the patient's mobile phone. Sensors and central hub are built-in the patient's shirt, and the information is transmitted to the mobile phone by Bluetooth.

The architecture of the patient health status monitoring system based on sensors is considered in paper [9]. Biosensors are constantly picking up signals about the physiology of the patient and transmitting them to a central node and based on the use of a smartphone and a microcontroller. Before being sent to the central site, messages are digitally converted if they are generated in analog form. The biosensors and center node are connected using wireless technologies (Bluetooth, Zigbee, etc.).

Monitoring systems of physiological health status indicators for patients with Alzheimer's disease for support of data transmission by Bluetooth are described in papers [7. 8]. The system records the patient movement in the house, and collected information about his location at a certain moment of time is transmitted to the hospital.

The issues of reading in the biomedical indicators of patients' health status by IoT devices, using cloud computing technologies and Big Data to transmit, store, and process them in real time are considered in papers [11-13], and the problems of miniaturization of nodes and sensors that can monitor important parameters of human health status are dealt with in papers [18-20].

In early 2020, the world faced the outbreak of COVID-19 viral disease. After the first confirmed disease case in China, the virus rapidly spread in the country and during the first month infected tens of 
thousands of people. Such case generated the task of urgent location tracking and controlling the migration of a large number of people.

To solve the problem of coronavirus control, the functionality of about 10 mobile applications was developed and tested. In February 2020, the application (YiKuang) was introduced for testing possible contact with infected persons, which enabled to track the presence of infections in a particular home, entrance, plane or bus used by the traveler during the last 14 days. The application access is by special QR code. Registration requires the mobile telephone number entry and person verification, by entering the user real name and passport number. The application makes it possible to collect information about the most dangerous places in where coronavirus infection is spread, as well as to identify crowded public areas (in order to be avoided by the users).

QuantUrban and WeChat Companies developed the platform that uses information from official sources (based on officially confirmed infection cases) and creates real maps of places and territories directly associated with an increased risk of coronavirus infection.

TraceTogether app, which notifies the user if a person with positive virus testing result is near by (Bluetooth technology) [21] is used in Singapore and StopCovid application [22], which notifies the user about the contact with infected person by Bluetooth technology is used in France.

In Israel and Turkey the infected citizens and their contacts monitoring is carried out by the telephone monitoring technology traditionally reserved for counter-terrorism operations. If a person with positive COVID-19 virus testing result or in close contact with the infected one breaks the quarantine laws, a text message or a phone call ordering to return home is automatically sent to him/her. If such warning is ignored, the police is informed in order to take necessary measures.

Technologies of Bluetooth signal analysis from users' smartphones enabling to collect information about people location, contacts, and to control keeping to quarantine rules introduced in the country are used in the United Kingdom, Germany, Poland, Spain, and other EU countries. Smartphones are also used to examine people health status by messaging surveys, recording their messages in patient medical record by means of different data input forms providing the combination of information about the user's location and health status becoming the basis for person health status "estimate" generation) [23]. Bluetooth-based technologies provide accurate determination of the smartphone user "contacts" on the basis of analysis of the so-called "handshake between devices" duration and strength.

The above mentioned applications use makes it possible to obtain and analyze health status information of a large number of people, promoting rapid and accurate identification of geographical regions, including cities, counties, villages where the virus is circulating, and to estimate the risks of staying in that region, so healthcare institutions and medical service providers can prepare the necessary resources better.

The smart city concept in the context of viral disease control focuses on the application of Big Data analysis methods and the improvement of forecasting procedures and emergency treatment protocols.

\section{The concept of multi-level mobile personalized system development}

The experience of Covid-19 pandemic control indicates the imperfection of existing systems of preventive population testing, i. e. the lack of systematic approach for decision-making with the possibility of making adjustments in the disease diagnosis processes. One of the sticking point of viral diseases spread is timely diagnosing, establishing the contact persons circle, monitoring the compliance with self-isolation requirements.

The authors propose the concept for the development of multilevel mobile personalized system based on the combination of consumer-server architecture and "publication-subscription" interaction concept.

Structural organization of "publication-subscription" interaction concept for tasks related to personalized medical services supply involves the implementation of users identification procedure; data transmission from sensors; module of local calculations and results presentation. The global database is formed on the server and comprehensive analysis is carried out. Its results can be used for identifying, monitoring, analyzing treatment processes or peculiarities of certain diseases progression.

The system is designed for comprehensive and effective healthcare professionals assistance, particularly in viral diseases control and for the improvement of health care services quality. The main functions of this system are as follows:

Communicational, which provides the main actors mobility, wireless high-speed communication and geopositioning. 
Informational which promotes the patients identification, links databases "PATIENT", "DOCTOR" and "POSITIONING", as well as telemetry logs keeping.

Medical - diagnosis, modeling and prediction of treatment procedures based on the obtained data, selection of effective treatment protocols and provision of personalized services, development of recommendations for doctors and patients concerning effective actions aimed at getting over the disease.

Figure shows the general diagram of remote health status monitoring system using IoT services and $5 \mathrm{G}$ data transmit technology.

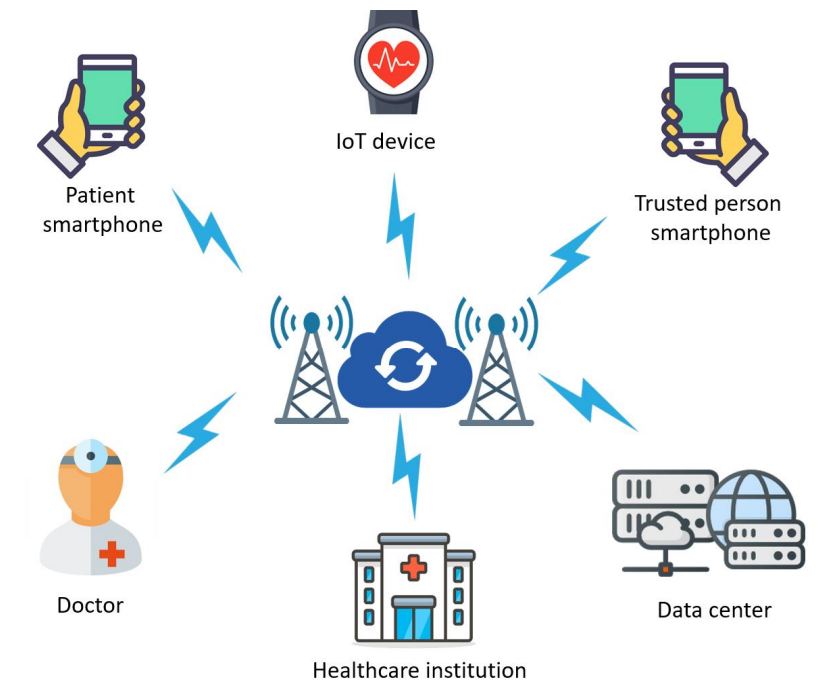

Diagram of remote monitoring of patient health status indicators

Terminal devices using IP-protocol provide data collection and transmission. After authorization, the customer or his/her agents gain access to the collected data by interacting with web-server according to customer-server principle.

The system performs the following tasks: automation of telemetry data acquisition technologies using IoT sensors; determination of the patient location; analysis of the collected data; immediate response to critical changes in health status indicators; provision of on-line diagnosis with individual approach to the patient; expansion of the telecommunication technologies use by telemedicine implementation on the basis of mobile operator networks; improvement of the quality and level of medical services supply for different population groups.

The comprehensive solution is used in order to increase the efficiency of the epidemic outbreak control this is synthesis of three main technologies, mainly Internet of Things, social networking environment and Big Data analytics. The result of such solution implementation is to combine data with complex event processing system, to assign context to these integrated data, and to create the patients profile.

The person positioning subsystem uses universal GPS in conjunction with GSM and, when connected to A-GPS and WIFI, to implement the external positioning function. For more accurate positioning and getting information about possible people contacts, information from Bluetooth and Wi-Fi is used as a priority from the data set.

Its functional tasks are as follows: first, the positioning method should operate continuously, and the most optimal positioning mean is automatically selected for different scenarios; second, the internal positioning system operates using Wi-Fi-based wireless local network. Positioning accuracy is ensured by modern intelligent elements of the smart city, smart watches, smartphones, etc. with positioning functions outdoors and indoors. Let us consider the positioning technologies used in the system:

Bluetooth - is the wireless technology standard for data exchange between fixed and mobile devices over short distances, using shortwave UHF radiowaves in industrial, scientific and medical radiofrequencies, from 2.40 to $2.480 \mathrm{GHz}$ and creation of personal area networking (PAN). The use of technology for positioning purposes requires notification of neighboring devices about the time and possible contact with sick person at the average distance of 5 meters.

GSM - (Global Mobile Communications System) - is the digital mobile telephony system. The advantage of this technology is its wide application. GSM operates in the frequency range $900 \mathrm{MHz}$ and 
$1800 \mathrm{MHz}$ 2.2 GPRS To determine the position, some signal or location parameters dependent on the location are required. (3) The Global Positioning System (GPS) is a space-based navigation system providing information about the place and time of stay at any point on the Earth's surface.

GPS generates specially coded satellite signals that are processed by GPS receiver, allowing the receiver to calculate location, speed and time. (6) Disadvantages of the usual GPS are: time of the first coordinates determination depends on the relevance of the stored in receiver almanac transmitted by GPS signal and on the orbital data (ephemeris). The device which is not active for a long period requires more time for possible position determination.

Auxiliary GPS or supplemented GPS (A-GPS) is the system greatly improving startup performance, such as, acceleration of the GPS receiver "cold start". The acceleration is due to information obtained by alternative communication channels. A-GPS is widely used for mobile phones supporting GPS. First of all, it was created for emergency calls managers. It is considered to be one of the best wireless positioning technologies under low signal conditions. A-GPS is able to work in cellular networks. A-GPS uses satellite communication to determine the location. This technology uses original information from mobile base stations. The main advantage is: quick coordinates receiving immediately after connection. A-GPS does not function outside the cellular network coverage area. [7]

Wi-Fi is the solution for positioning of the wireless local network of IEEE 802.11 standard. The system uses the combination of empirical testing and signal propagation models, it is easy to install, requires a small number of base stations, can use the same basic wireless network structure, and has high overall system accuracy.

Using different technologies, cloud server stores the positioning data obtained from different devices, and the application accesses API to display and analyze the positioning data in real time. Due to the technologies combination, internal and external positioning can be used with a certain accuracy degree, being useful for various medical and emergency situations and analysis and the following processing by other smart city information systems.

\section{Conclusions}

The result of the given investigation is the development of the conceptual model of multi-level mobile personalized health status monitoring system used for intellectual data analysis, prediction, treatment and prevention of viral diseases such as Covid-19 in modern "smart city".

\section{References}

1. Falat P., Pasichnyk V., Kunanets N., Martsenko S., Matsiuk O., Mytnyk O., Duda O. (2018). Telecommunication infrastructures for telemedicine in smart cities. CEUR Workshop proceedings, Vol. 2255, 256-266.

2. Wac K., Konstantas D., Halteren A. V., Bults R., Widya I., Dokovsky N., Koprinkov G., Jones V., Herzog Rainer. (2004). Mobile patient monitoring: the mobihealth system. J. Inf. Technol. Healthcare, No. 2 (5), 365-373.

3. Noah B., Keller M. S, Mosadeghi S., Stein L., Johl S., Delshad S., et al. (2018). Impact of remote patient monitoring on clinical outcomes: an updated meta-analysis of randomized controlled trials. npj Digital Med., No. 1, 20172.

4. Park J., Kim J., Kim S. Y., Cheong W. H., Jang J., Park Y. G., et al. (2018). Soft, smart contact lenses with integrations of wireless circuits, glucose sensors, and displays. Sci Adv., Vol. 4. Access mode: https://advances.sciencemag.org/content/4/1/eaap9841

5. Chu M. X., Miyajima K., Takahashi D., Arakawa T., Sano K, Sawada S., et al. (2011). Soft contact lens biosensor for in situ monitoring of tear glucose as non-invasive blood sugar assessment. Talanta, Vol. 83, 960-965.

6. Barnickel J., Karahan H., Meyer U. (2010). Security and Privacy for Mobile Electronic Health Monitoring and Recording Systems. Access mode: https://ieeexplore.ieee.org/abstract/document/5534981

7. Ting H., Zhuang W. (2010). Bluetooth-Enabled In-home Patient Monitoring System: Early Detection of Alzheimer's disease. IEEE Wireless Comm., Vol. 17, 74-79.

8. Suji Pramila R., Shajin Nargunam A. (2012). A Study On Data Confidentiality In early Detection Of Alzheimer's Disease. Access mode: https://ieeexplore.ieee.org/document/6203917

9. Pantelopoulos A., Bourbakis N. G. (2010). A Survey on Wearable Sensor-Based Systems for Health Monitoring and Prognosis, IEEE Transactions on Systems, Man and Cybernetics, Vol. 40, No. 1, 1-12.

10. Yifeng He, Wenwu Zhu, Ling Guan (2011). Optimal Resource Allocation for Pervasive Health Monitoring Systems with Body Sensor Networks. IEEE Transactions on Mobile Computing, Vol. 10, No. 11, 1558-1575.

11. Dhawan W., Heetderks M., Pavel S., Acharya M., Akay A., Gerber M. (2015). Current and future challenges in point-of-care technologies: A paradigm-shift in affordable global healthcare with personalized and preventive medicine. IEEE Journal of Translational Engineering in Health and Medicine, Vol. 3, pp. 1-10.

12. Goetghebeur M., Wagner M., Samaha D., O'Neil W., Badgley D., Jaramillo H., Tringali M. (2017). Exploring values of health technology assessment agencies using reflective multicriteria and rare disease case. International Journal of Technology Assessment in Health Care, Vol. 33, Iss., 4, 504-520. 
13. Aziz K., Tarapiah S., Ismail S., Atalla S. (2016). Smart real-time healthcare monitoring and tracking system using GSM/GPS technologies. Access mode: https://ieeexplore.ieee.org/document/7460394

14. Farahat I., Tolba A., Elhoseny M., Eladrosy W. (2019). Data security and challenges in smart cities. Security in Smart Cities: Models, Applications, and Challenges, 117-142.

15. Reis S., Seto E., Northcross A., Quinn N., Convertino M., Jones R., Wimberly M., (2015). Integrating modelling and smart sensors for environmental and human health. Environmental Modelling and Software, Vol. 74, $238-246$.

16. Sivanathan D., Sherratt H., Gharakheili A., Radford C., Wijenayake A., Vishwanath V., Sivaraman V. (2017). Characterizing and classifying IoT traffic in smart cities and campuses. Access mode: https://ieeexplore.ieee.org/document/8116438

17. Clim A. (2019). Cyber security beyond the Industry 4.0 era. A short review on a few technological promises. Informatica Economica, Vol. 23(2), 34-44.

18. Hossain M. (2016). Patient status monitoring for smart home healthcare: IEEE International Conference on Multimedia \& Expo Workshops (ICMEW), 1-6.

19. Clim R., Zota R., Constantinescu R., Nemedi I. (2019). Health Services in Smart Cities: Choosing the Big Data Mining Based Decision Support. International Journal of Healthcare Management, Vol. 13, Iss. 1, $79-87$.

20. Patsakis C., Venanzio R., Bellavista P., Solanas A., Bouroche M. (2014). Personalized medical services using smart cities' infrastructures: IEEE International Symposium on Medical Measurements and Applications. Available at: https://ieeexplore.ieee.org/document/6860145

21. TraceTogether,safer together. (2020). Available at: https://www.tracetogether.gov.sg/

22. Mobilisation générale pour développer l'application StopCovid. (2020). Available at: https://www.lefigaro.fr/secteur/hightech/mobilisation-generale-pour-developper-1-application-stopcovid-20200426

23. Ventola C. L. (2014). Mobile devices and apps for health care professionals: uses and benefits. $P$ T, Vol. 39(5), 356-36

\title{
МОБЛЬНА ІНФОРМАЦІЙНА СИСТЕМА ДЛЯ МОНІТОРИНГУ ПОШИРЕННЯ ВІРУСІВ У РУМНИХ МІСТАХ
}

\author{
Олексій Дуда ${ }^{1}$, Ліліана Джиджора ${ }^{1}$, Олександр Мацюк ${ }^{1}$, Андрій Станько $^{1}$, \\ Наталія Кунанець², Володимир Пасічник², Оксана Кунанець \\ ${ }^{1}$ Тернопільський національний університет ім. І. Пулюя \\ oleksij.duda@gmail.com, ORCID 0000-0003-2007-1271 \\ oleksandr.matsiuk@gmail.com, ORCID 0000-0003-0204-3971 \\ lilyadzhydzhora1970@gmail.com, ORCID 0000-0002-3672-4807 \\ stanko.andrjj@gmail.com, ORCID 0000-0002-5526-2599 \\ ${ }^{2}$ Національний університет "Львівська політехніка" \\ nek.lviv@gmail.com, ORCID 0000-0003-3007-2462 \\ vpasichnyk@gmail.com, ORCID 0000-0002-5231-6395 \\ oksanka.kun@gmail.com, ORCID 0000-0001-8626-9016
}

(С Дуда О., Джиджора Л., Мацฺюк О., Станько А., Кунанецьь Н., Пасічник В., Кунанецьь О., 2020

Була розроблена концепція створення багаторівневої мобільної персоніфікованої системи боротьби 3 вірусними захворюваннями, зокрема Covid-19. Використовуючи інтеграцію Інтернету речей, хмарних обчислень та технологій великих даних, система передбачає посднання двох архітектур: кліснт-сервер та публікацію-передплату. Перевагою системи с постійна допомога при вірусних захворюваннях, а саме на стадіях спілкування, інформації та лікування. Концепція розумного міста в контексті боротьби з вірусними захворюваннями фокусується на застосуванні методів аналізу великих даних та вдосконаленні процедур прогнозування та протоколів екстреного лікування. Використовуючи різні технологї, хмарний сервер зберігає дані про позиціонування, отримані з різних пристроїв, а програма отримує доступ до АРІ для відображення та аналізу даних про позиціонування в режимі реального часу. Завдяки поєднанню технологій, внутрішне та зовнішне позиціонування можна використовувати 3 певною мірою точності, корисно для різних медичних та надзвичайних ситуацій та аналізу і подальшого опрацювання іншими інформаційними системами розумного міста. Результатом цього дослідження є розробка концептуальної моделі багаторівневої мобільної персоніфікованої системи моніторингу стану здоров'я, що використовується для інтелектуального аналізу даних, прогнозування, лікування та профілактики вірусних захворювань, таких як Covid-19, у сучасному “розумному місті”.

Ключові слова: розумне місто, ІоТ, вірус. 